Психолого-педагогічні проблеми становлення сучасного фахівця Випуск 2018

УДК 37.015.3:37.032

DOI 10.26697/9786177089017.2018.183

(C) Белікова О. В., Бессонова Н. М., 2018

(C) Греул О. О., Дитюк С. О., Тесаловська О. Б., 2018 Бєлікова Олена Віталіївна

Харківський національний університет будівництва та архітектури

Бессонова Наталія Миколаївна

Харківський національний університет будівництва та архітектури

Греул Ольга Олександрівна

Харківський національний університет будівництва та архітектури

Дитюк Світлана Олексіївна

Харківський національний університет будівництва та архітектури

Тесаловська Ольга Борисівна

Харківський національний університет будівництва та архітектури

\title{
ПСИХОЛОГО-ПЕДАГОГІЧНА КОМПЕТЕНТНІСТЬ ВИКЛАДАЧА З МОВНОЇ ПІДГОТОВКИ ІНОЗЕМНИХ ГРОМАДЯН
}

У статті здійснено аналіз поняття «діагностика професійних компетенцій викладача мовної підготовки іноземних громадян», визначена роль $і$ місие діагностики в системі професіографічного моніторингу, виділені компетениіі викладача з навчання мови іноземних студентів технічних спеціальностей. Компетентнісний підхід передбачає пошук нових методологічних моделей підготовки фахівиів із вищою технічною освітою, підвищення якості підготовки професійних кадрів, визначення ключових компетениій, якими повинен користуватися сучасний викладач.

Ключові слова: компетентнісний підхід, педагогічна діагностика, професійна компетениія, професіографічний моніторинг, якості викладача мовної підготовки іноземних громадян.

Проблема, її зв'язок із важливими науковими чи практичними завданнями. Модернізація вищої освіти, що відбувається протягом останніх років під впливом глобальних перетворень в Україні та загально-цивілізованих процесів у світі, спрямовується на підвищення якості професійної підготовки фахівців. В умовах соціально-економічних змін в Україні, вдосконалення системи вищої професійної освіти, в процесі впровадження нових вимог і стандартів навчання відбуваються значні трансформації у взаємодії викладача та студента. Зміни, в першу чергу, стосуються сприйняття викладача, змінюється система рольових очікувань щодо провідних якостей педагога. Саме тому одним із найгостріших питань у сучасних педагогічних дискусіях стає питання про особистість 
педагога, його професійну діяльність, про вимоги, що висуваються до нього.

Аналіз публікацій (виділення невирішених проблем). Аналіз останніх досліджень i публікацій свідчить, що ця проблема $\epsilon$ багатоперспективною. Актуальну проблему професійно значущих якостей педагога досліджували такі вчені, як I. Зімня, І. Зязюн, I. Подласий, В. Сластенін, Е. Клімов, М. Харламов та інші [2, с. 258]. Головні думки, які об'єднують різні точки зору цих досліджень, полягають у тому, що викладач закладу вищої освіти - це особистість, яка за змістом своєї професійної діяльності повинна володіти сукупністю професійних якостей: бути вченим, педагогом-практиком, вихователем, психологом, володіти технологією навчально-виховного процесу та забезпечувати органічне об'єднання в процесі навчання освітньої, наукової та інноваційної діяльності [1; 6; 8; 10]. Психолог В. А. Крутецький пропонує таку структуру професійно значущих якостей особистості викладача: світогляд, позитивне ставлення до педагогічної діяльності, педагогічні здібності, професійно-педагогічні знання, вміння, навички [3, с. 78].

Т. І. Руднева додає до змісту професійної компетенції викладача когнітивний компонент і практичні навички [9, с. 56].

Т. М. Ткачова акцентує увагу на особистісних якостях викладача як основоположних, що впливають на якість професійної підготовки випускників ЗВО. «Вплив педагога складається 3 прояву його професійних якостей як людини, яка добре знає свій предмет, i впливу його особистості, духовності, емоційності. При цьому особистісні якості набагато важливіші для студента, ніж професійні.

Висока оцінка викладача студентами майже завжди гарантує любов учнів до нього та до його предмета» [10, с. 77].

Сукупність професійно обумовлених вимог до педагога визначається як професійна готовність до педагогічної діяльності. В іiі складі правомірно виділити, 3 одного боку - психологічну, психофізичну та фізичну готовність, а з іншого боку, - науковотеоретичну та практичну компетентність як основу професіоналізму. Система професійно обумовлених вимог до педагога становить зміст професійної компетенції викладача. До теперішнього часу накопичений багатий досвід побудови системи професійної компетенції викладача, який дозволяє об'єднати професійні вимоги у три основні групи, що взаємопов'язані та доповнюють одна одну: загальногромадянські якості; якості, що визначають специфіку професії викладача; спеціальні знання та навички [8, с. 226].

Важливим елементом прогностичного підходу виступає професіографічний моніторинг. 
Психолого-педагогічні проблеми становлення сучасного фахівця Випуск 2018

Ціль статті - дослідження й обгрунтування теоретичних основ діагностики результатів формування професійних компетенцій педагогів із мовної підготовки іноземних громадян у закладах вищої освіти.

Виклад основного матеріалу, обгрунтування результатів дослідження. Враховуючи специфіку процесу навчання мови іноземних студентів, можна говорити про те, що викладач із мовної підготовки іноземних громадян:

- повинен володіти знаннями не тільки в галузі методики викладання мови, але й у галузі культури тієї країни, представниками якої є студенти, що вивчають мову;

- $\epsilon$ носієм культури країни мови, що вивчається;

- в навчальному процесі виконує функції носія не тільки вітчизняної, а й зарубіжної культури, звертаючи увагу студентів на різні аспекти культури інших країн, сприяє їх залученню до цінностей культур різних народів;

- повинен володіти культурою мови, що виражається в правильності мовлення, в необхідному виборі для конкретної мети мовних засобів (точності, чистоті, виразності, багатстві та різноманітності мовлення), в дотриманні мовленнєвого етикету.

Аналізуючи психолого-педагогічну літературу щодо визначення дефініцій вищенаведених понять, ми дійшли висновку, що виділяють такі компетенції викладача з мовної підготовки іноземних громадян [2$5 ; 9 ; 10]$ :

1. Загальногуманітарна компетенція. Проблеми міжкультурної комунікації можуть бути ефективно вирішені лише за умов сформованості достатнього рівня загальногуманітарної компетенції.

2. Лінгвістична компетенція. Комплекс знань системи мови, що вивчається, $є$ провідною компетенцією викладача мовної підготовки.

3. Психологічна компетенція. Навчання мови буде успішним, якщо викладач буде враховувати індивідуально-особистісні особливості студентів; психологію педагогічної діяльності, навчальнопедагогічного співробітництва та спілкування.

4. Педагогічна компетенція. Знання фундаментальних педагогічних концепцій, законів i закономірностей, основних педагогічних категорій і понять, прикладні знання про загальну методику навчання дозволять оптимізувати процес навчання.

5. Методична компетенція. Основа цієї компетенції полягає в знанні теорій, концепцій, методичної системи навчання мови іноземних студентів; у володінні метамовою, системою понять; у знанні та володінні прийомами, методами та способами навчання мови іноземних студентів. 


\section{Збірник наукових статей}

6. Професійно-комунікативна компетенція. Уміння встановити педагогічно оптимальні стосунки 3 усіма учасниками навчальнопедагогічного процесу, що є умовою його ефективності.

Для вивчення особливостей сприйняття особистості викладача мовної підготовки іноземних громадян, які $є$ значущими для студентів нашого закладу вищої освіти, нами було проведено опитування: «Викладач очима іноземних студентів». У ньому взяли участь студенти будівельного й архітектурного факультетів ХНУБА. Нами були поставлені певні завдання для вивчення особистості сучасного викладача, а саме визначити:

1) загальні уявлення іноземних студентів про вимоги, що висуваються до викладача закладу вищої освіти;

2) найбільш значущі для іноземних студентів характеристики в професіограмі викладача;

3) динаміку уявлень образу викладача закладу вищої освіти в оцінках іноземних студентів на різних курсах навчання.

Це дослідження проводилося в кілька етапів. На першому етапі експерименту студентам-іноземцям 3-5 курсів пропонувалося закінчити речення: «Сучасний викладач ЗВО повинен бути...», використовуючи власні формулювання. Після обробки результатів цих опитувань був складений список значущих для студентів характеристик особистості викладача. Студентам 1-2 курсів пропонувалося проранжувати характеристики особистості викладача 3 отриманого списку. Аналіз результатів опитування показав наявність двох основних груп: професійних якостей та особистісних якостей викладача.

Згідно 3 результатами нашого опитування іноземні студенти вважають, що викладачу мають бути притаманні такі якості: професіоналізм (при цьому використовувалися формулювання «добре пояснювати», «зрозуміло пояснювати», «пояснювати складні питання», «пояснювати просто», «добре відповідати на питання»), риторична майстерність («цікаво розповідати», «хороша мова», «вибирати прості речення», «говорити чітко»), комунікабельність («добре спілкуватися», «спілкуватися шанобливо», «культурно спілкуватися», «бути близько до студента», «дружити зі студентами»), широкий світогляд («відкритий розум», «розумний», «багато знати»), знання навчального предмета («знати предмет», «глибокі знання»), доброзичливість («добрий», «добрі стосунки зі студентами», «хороший характер», «допомагати студенту»), вміння володіти собою («не кричати», «не знущатися», «спокійний», «терплячий»), інтернаціоналізм («не бути расистом», «розуміти, що всі студенти рівні: українські та іноземні»), толерантність («поважати нашу культуру», «поважати нашу релігію»), зовнішній вигляд («гарний», 


\section{Психолого-педагогічні проблеми становлення сучасного фахівця Випуск 2018}

«акуратний»), емпатія («допомагати студенту»), вимогливість, об'єктивність, шанобливе ставлення до студента.

Найбільш частотними виявилися такі характеристики: «не бути расистом» - 60\%, «добре пояснювати» - 55\%, «знати предмет» $-40 \%$, «розумний» - 38\%, «добрий» - 32\%, «терплячий, спокійний» $-33 \%$, «добрі стосунки зі студентами» - 30\%, «комунікабельний» - 30\%, «поважати студента»- $27 \%$.

Під час порівняльної характеристики ранжирування якостей студентами молодших і старших курсів нами були виявлені такі закономірності.

Студенти молодших курсів надають значення не стільки професійним якостям, науковому рівню, глибині знань викладача, скільки ставленню викладача до самих студентів: для студентапершокурсника важливо, як із ним спілкуються, наскільки доброзичливий, терплячий і тактовний викладач у спілкуванні 3 ним. При оцінці образу сучасного викладача вони значною мірою орієнтуються на його особистісні якості, систему доброзичливих i поважних стосунків між студентом і викладачем. На перше місце студенти 1-2 курсів ставлять таку якість, як «шанобливе ставлення до студента», на друге - «інтернаціоналізм», на третє «доброзичливість» i «комунікабельність», на четверте - «вміння зрозуміло пояснювати», на п'яте - «розуміти студента» та «допомагати студенту».

Студенти 3-5 курсів рівною мірою оцінюють систему особистісних взаємин із викладачем і знання навчальної дисципліни викладання, вміння риторично грамотно викладати навчальний матеріал. Вони виділяють такі якості, що характеризують професійні та особистісні якості викладача: «добре знання предмета» і «вміння пояснювати» (1 ранг); «шанобливе ставлення до студента» i «доброзичливість» (2 ранг); «вміння володіти собою» (3 ранг); «об'єктивність оцінювання знань студента» і «комунікабельність» (4 ранг); «зовнішній вигляд» (5 ранг), «інтернаціоналізм» (6 ранг).

Проаналізувавши ці дані, можна зробити такі висновки:

- у викладачеві мовної підготовки іноземних громадян студенти повинні бачити патріота України. При цьому в його діяльності абсолютно неприпустимі прояви націоналізму, зневажливого ставлення до представників будь-якої іншої країни, будь-якої іншої національності;

- образ викладача закладу вищої освіти складається з багатьох суб'єктивних факторів сприйняття студентів і містить декілька груп якостей: індивідуально-особистісні, що характеризують викладача як особистість; професійні, що характеризують його професійну 


\section{Збірник наукових статей}

діяльність; соціальні, що характеризують комунікативні якості викладача, взаємодію з учасниками освітнього процесу;

- у процесі навчання студентів уявлення і складника образу викладача зазнають змін;

- ефективність і оптимізація процесу навчання мови іноземних учнів залежить як від педагогічного професіоналізму - знань і умінь в галузі лінгвістики, країнознавства, методики, педагогіки та психології, так і від індивідуально-психологічних особливостей особистості викладача.

Висновки, перспективи. Таким чином, посилення уваги до питань діагностування рівня володіння викладачами 3 мовної підготовки професійними компетенція потребує не тільки науковообгрунтованого інструментарію щодо постійного вимірювання, аналізу й удосконалення оцінювання навчальних результатів професійної підготовки студентів, але й нового погляду на систему педагогічної діагностики. Системна діагностика на підставі компетентнісного підходу повинна стати ключовим i наскрізним компонентом моніторингу якості професійної підготовки фахівців із мовної підготовки в закладах вищої освіти технічного напряму. Метою подальших досліджень є розкриття сутності та структури складників системи діагностики професійних компетенцій; визначення інваріативного та варіативного складників професійних компетенцій педагога 3 мовної підготовки іноземних громадян; обгрунтування моделі та методики застосування системної діагностики професійних компетенцій.

\section{Література}

1. Андреева Г. М. Социальная психология : учебник для высш. учеб. заведений. 5-е изд., испр. и доп. - Москва : Аспект. Пресс, 2014. -362 c.

2. Зимняя И. А. Педагогическая психология : учебник для вузов. 3-е изд. доп. - Москва : Моск. психол.-соц. ин-т ; Воронеж : МОДЭК, 2010. -448 c.

3. Компетентностный подход в современном образовании: мировой опыт и украинские перспективы: Библиотека по образовательной политике / под общ. ред. О. В. Овчарук. - Москва : К.И.С., 2004. - 112 с.

4. Компетентность саморазвития специалиста: педагогические основы формирования в высшей школе / наук. ред. Н. В. Кичук. Измаил : ИГГУ, 2007. - 236 с.

5. Ортинський В. Л. Педагогіка вищої школи : навч. посіб. Київ : Центр учбової літератури, 2017. - 470 с. 
Психолого-педагогічні проблеми становлення сучасного фахівця Випуск 2018

6. Панина С. В. Самоопределение и профессиональная ориентация учащихся : учебник и практикум для академического бакалавриата / С. В. Панина, Т. А. Макаренко. - 3-е изд., испр. и доп. Москва : Юрайт, 2017. - 312 с.

7. Подласий И. П. Педагогика / И. П. Подласий. - Москва : ВЛАДОС, 2015. - 398 с.

8. Руднева Т. И. Профессиональная подготовка специалистов гуманитарного профиля: монография / Т. И. Руднева, С. В. Астахова, Е. С. Лапшова. - Самара : Изд-во Самар. ун-та, 2008. - 249 с.

9. Сластенин В. А. Педагогика : учеб. пособие для студ. высш. пед. учеб. заведений / В. А. Сластенин, И. Ф. Исаев, Е. Н. Шиянов. Москва : Школа-Пресс, 2015. - 512 с.

10. Ткачова Т. М. Роль личности в обеспечении качества профессиональной подготовки выпускников вуза: учеб. пособие. Москва : МАДИ, 2015. - 76 с.

Елена Беликова, Наталья Бессонова, Ольга Греул, Светлана Дытюк, Ольга Тесаловская. Психолого-педагогическая компетентность преподавателя языковой подготовки иностранных граждан.

B cтатье осуществлен анализ понятия «диагностика профессиональных компетенций преподавателя языковой подготовки иностранных граждан», определена роль и место диагностики в системе профессиографического мониторинга, выделень компетенции преподавателя по обучению языку иностранных студентов технических специиальностей. Компетентностный подход связан с поиском новых концептуально-методологических моделей подготовки специалистов с высшим техническим образованием, качеством подготовки профессиональных кадров, определением ключевых компетенций, которыми должен владеть современный преподаватель.

Ключевье слова: качества преподавателя языковой подготовки иностранных граждан, компетентностный подход, педагогическая диагностика, мониторинг, профессиональная компетенция.

Olena Belikova, Natalia Bessonova, Olga Greul, Svitlana Dytuk, Olga Tesalovskaya. Psychological and pedagogical competency of foreign students language lecturer.

The article analyzes the concept of «diagnostics of the professional competencies of the lecturer of language training for foreign citizens», defines the role and place of diagnosis in the system of professional monitoring, highlights lecturer's competence in teaching foreign students of technical specialties. The theoretical bases of diagnostics and 
determination of the results of the formation of professional competencies of language training lecturer's for foreign citizens as the actual pedagogical problem in universities of technical profile were investigated and substantiated. In the conditions of socio-economic changes in Ukraine, the improvement of higher professional education system, in the process of introducing new requirements and standards of education, there are significant transformations in the system «lecturer-to-student». Changes in the first place concern perception of lecturer, the system of role expectations regarding the leading qualities of the lecturer changes. Strengthening the attention to the issues of diagnosing the level of proficiency of language training lecturers of professional competences, as a modern trend requires not only scientifically based tools for continuous measurement, analysis and improvement of evaluation of educational results of students' professional training, but also a new look at the system of pedagogical diagnostics. System diagnostics based on a competent approach should become a key and crosscutting component of monitoring the quality of vocational training of language training specialists in universities of technical profile.

Keywords: lecturer's professional competence, language training, monitoring, foreign students, universities of technical profile.

Стаття надійшла до редакційної колегії 24.04.2018

Прийнято до друку 08.05.2018

\section{Інформація про авторів:}

Бєлікова Олена Віталіївна - старший викладач кафедри української мови та мовної підготовки іноземних громадян, Харківський національний університет будівництва та архітектури.

Бессонова Наталія Миколаївна - старший викладач кафедри української мови та мовної підготовки іноземних громадян, Харківський національний університет будівництва та архітектури.

Греул Ольга Олександрівна - старший викладач кафедри української мови та мовної підготовки іноземних громадян, Харківський національний університет будівництва та архітектури.

Дитюк Світлана Олексіївна - старший викладач кафедри української мови та мовної підготовки іноземних громадян, Харківський національний університет будівництва та архітектури.

Тесаловська Ольга Борисівна - старший викладач кафедри української мови та мовної підготовки іноземних громадян, Харківський національний університет будівництва та архітектури. 